\title{
Nitrous oxide emission from highland winter wheat field after long-term fertilization
}

\author{
X. R. Wei ${ }^{1,2}$, M. D. Hao ${ }^{1,2}$, X. H. Xue ${ }^{2}$, P. Shi ${ }^{1}$, R. Horton ${ }^{3}$, A. Wang ${ }^{1}$, and Y. F. Zang ${ }^{1}$ \\ ${ }^{1}$ Institute of Soil and Water Conservation, Northwest Sci-Tech. University of Agriculture \& Forestry, Yangling, Shaanxi \\ Province, China \\ ${ }^{2}$ State Key Laboratory of Soil Erosion and Dryland Farming on the Loess Plateau, Institute of Soil and Water Conservation, \\ CAS and MWR, Yangling, Shaanxi Province, China \\ ${ }^{3}$ Department of Agronomy, Iowa State University, Ames, Iowa, USA
}

Received: 9 April 2010 - Published in Biogeosciences Discuss.: 16 June 2010

Revised: 6 October 2010 - Accepted: 12 October 2010 - Published: 27 October 2010

\begin{abstract}
Nitrous oxide $\left(\mathrm{N}_{2} \mathrm{O}\right)$ is an important greenhouse gas. $\mathrm{N}_{2} \mathrm{O}$ emissions from soils vary with fertilization and cropping practices. The response of $\mathrm{N}_{2} \mathrm{O}$ emission to fertilization of agricultural soils plays an important role in global $\mathrm{N}_{2} \mathrm{O}$ emission. The objective of this study was to assess the seasonal pattern of $\mathrm{N}_{2} \mathrm{O}$ fluxes and the annual $\mathrm{N}_{2} \mathrm{O}$ emissions from a rain-fed winter wheat (Triticum aestivum $\mathrm{L}$.) field in the Loess Plateau of China. A static flux chamber method was used to measure soil $\mathrm{N}_{2} \mathrm{O}$ fluxes from 2006 to 2008. The study included 5 treatments with 3 replications in a randomized complete block design. Prior to initiating $\mathrm{N}_{2} \mathrm{O}$ measurements the treatments had received the same fertilization for 22 years. The fertilizer treatments were unfertilized control $(\mathrm{CK})$, manure $(\mathrm{M})$, nitrogen $(\mathrm{N})$, nitrogen + phosphorus $(\mathrm{NP})$, and nitrogen + phosphorus + manure (NPM). Soil $\mathrm{N}_{2} \mathrm{O}$ fluxes in the highland winter wheat field were highly variable temporally and thus were fertilization dependent. The highest fluxes occurred in the warmer and wetter seasons. Relative to $\mathrm{CK}, \mathrm{m}$ slightly increased $\mathrm{N}_{2} \mathrm{O}$ flux while N, NP and NPM treatments significantly increased $\mathrm{N}_{2} \mathrm{O}$ fluxes. The fertilizer induced increase in $\mathrm{N}_{2} \mathrm{O}$ flux occurred mainly in the first 30 days after fertilization. The increases were smaller in the relatively warm and dry year than in the cold and wet year. Combining phosphorous and/or manure with mineral $\mathrm{N}$ fertilizer partly offset the nitrogen fertilizer induced increase in $\mathrm{N}_{2} \mathrm{O}$ flux. $\mathrm{N}_{2} \mathrm{O}$ fluxes at the seedling stage were mainly controlled by nitrogen fertilization, while fluxes at other plant growth stages were influenced by plant
\end{abstract}

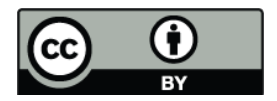

Correspondence to: M. D. Hao (mdhao@ms.iswc.ac.cn) and environmental conditions. The cumulative $\mathrm{N}_{2} \mathrm{O}$ emissions were always higher in the fertilized treatments than in the non-fertilized treatment (CK). Mineral and manure nitrogen fertilizer enhanced $\mathrm{N}_{2} \mathrm{O}$ emissions in wetter years compared to dryer years. Phosphorous fertilizer offset 0.50 and $1.26 \mathrm{~kg} \mathrm{~N}_{2} \mathrm{O}-\mathrm{N} \mathrm{ha}^{-1}$ increases, while manure + phosphorous offset 0.43 and $1.04 \mathrm{~kg} \mathrm{~N}_{2} \mathrm{O}-\mathrm{N} \mathrm{ha}^{-1}$ increases by $\mathrm{N}$ fertilizer for the two observation years. Our results suggested that the contribution of single $\mathrm{N}$ fertilizer on $\mathrm{N}_{2} \mathrm{O}$ emission was larger than that of NP and NPM and that manure and phosphorous had important roles in offsetting mineral $\mathrm{N}$ fertilizer induced $\mathrm{N}_{2} \mathrm{O}$ emissions. Relative to agricultural production and $\mathrm{N}_{2} \mathrm{O}$ emission, manure fertilization $(\mathrm{M})$ should be recommended while single $\mathrm{N}$ fertilization $(\mathrm{N})$ should be avoided for the highland winter wheat due to the higher biomass and grain yield and lower $\mathrm{N}_{2} \mathrm{O}$ flux and annual emission in $\mathrm{m}$ than in $\mathrm{N}$.

\section{Introduction}

Nitrous oxide $\left(\mathrm{N}_{2} \mathrm{O}\right)$, an important greenhouse gas in the atmosphere, has increased from pre-industrial concentrations of $270 \mathrm{ppb}$ to $319 \mathrm{ppb}$ in 2005 (Forster et al., 2007). Soil is acknowledged as the major source of $\mathrm{N}_{2} \mathrm{O}$, accounting for about $70 \%$ of total emissions. Agricultural soils account for a large proportion (70-81\%) of the increase in $\mathrm{N}_{2} \mathrm{O}$ emissions to the atmosphere, with the increase linked to increased $\mathrm{N}$ fertilizer use (Bouwman, 1990). A recent calculation showed that $3.3 \mathrm{Tg} \mathrm{N}_{2} \mathrm{O}-\mathrm{N} \mathrm{yr}^{-1}$ is emitted globally from fertilized cropland (Stehfest and Bouwman, 2006). However, the linkages between agricultural soil emissions and global

Published by Copernicus Publications on behalf of the European Geosciences Union. 
emissions are still uncertain (Stehfest and Bouwman, 2006), and further understanding of $\mathrm{N}_{2} \mathrm{O}$ emissions from cropped land are still necessary for accurate global $\mathrm{N}_{2} \mathrm{O}$ emission prediction.

The response of soil $\mathrm{N}_{2} \mathrm{O}$ emissions to $\mathrm{N}$ fertilizatioN has been widely studied in different ecosystems. Dittert et al. (2005) and Lampe et al. (2006) showed larger $\mathrm{N}_{2} \mathrm{O}$ emissions from mineral $\mathrm{N}$ than from slurry treated grassland plots and demonstrated that the soil $\mathrm{N}$ pool was always clearly the major source of $\mathrm{N}_{2} \mathrm{O}$. Zhang and Han (2008) reported a linear relationship between cumulative $\mathrm{N}_{2} \mathrm{O}$ and $\mathrm{N}$ application rate in the semi-arid grassland of northern China, while McSwiney \& Robertson (2005) found a nonlinear response of $\mathrm{N}_{2} \mathrm{O}$ flux to incremental fertilizer additions in a continuous maize (Zea mays L.) cropping system in southwest Michigan. Although the response pattern of soil $\mathrm{N}_{2} \mathrm{O}$ emission to $\mathrm{N}$ fertilizers was not identical, the increased $\mathrm{N}_{2} \mathrm{O}$ emission associated with mineral $\mathrm{N}$ fertilizer application is widely acknowledged (Bouwman et al., 2002). As for manure fertilizer, Davidson (2009) showed that manure has been important for $\mathrm{N}_{2} \mathrm{O}$ emission since 1860 , whereas mineral fertilizer became important only during the last half of the twentieth century, suggesting that the contribution of manure fertilizer to $\mathrm{N}_{2} \mathrm{O}$ emission cannot be ignored. However, estimations by Flynn et al. (2005) indicated that manure makes a significantly smaller contribution than mineral $\mathrm{N}$ fertilizers to $\mathrm{N}_{2} \mathrm{O}$ emissions from cropped soils. Many other studies also showed that $\mathrm{N}_{2} \mathrm{O}$ emission due to manure were less than that due to mineral $\mathrm{N}$ fertilizers (Dambreville et al., 2008; Alluvione et al., 2010). Nevertheless, little research has been performed to study how $\mathrm{N}_{2} \mathrm{O}$ emissions respond to a combined application of manure and mineral $\mathrm{N}$ fertilizers. Combinations of manure and mineral $\mathrm{N}$ fertilizers are used extensively around the world.

Manure fertilizer has been extensively applied to farmland in China for more than 2000 years. In the past 50 years, with the use of chemical fertilizers, manure and chemical fertilizers were often used together to increase crop yields (Shen, 1998). For example, in the central Loess Plateau, the average manure application rate before 1960 was 22.9 ton/ha. Chemical fertilizers were not used before 1960. Yet after 1960 the manure application rate was 24.9 toN ha $^{-1}$ and the chemical fertilizer rate was $178 \mathrm{~kg} \mathrm{ha}^{-1}$ (Hao et al., 1991). Therefore, even after chemical fertilizer applications became popular, manure still accounted for an important part of the total $\mathrm{N}$ applied to farmland soils in the area. Thus, the effects of manure on $\mathrm{N}_{2} \mathrm{O}$ emissions should be investigated.

Wheat is an important contributor to the global food supply. The global wheat area in 2007 was 210 million ha, while the area in China was 23 million ha. $\mathrm{N}$ fertilization is fundamental for wheat production. In 1996, a total of 4.97 million tons of $\mathrm{N}$ fertilizer were applied for global cereal production, and wheat accounted for approximately $29 \%$ of the total (Raun and Johnson, 1999). However, the nitrogen use efficiency of wheat is relatively low and $\mathrm{N}$ losses attract much attention from scientists (Xing and Zhu, 2000; Silgram et al., 2001; Bouwman et al., 2005; Sudling et al., 2005; Vitousek et al., 2009). As global wheat production expands, $\mathrm{N}$ fertilizer applications for wheat production increase, and the $\mathrm{N}$ fertilizer induced $\mathrm{N}_{2} \mathrm{O}$ emissions in wheat fields account for an increasing proportion of global $\mathrm{N}_{2} \mathrm{O}$ emissions. Further studies of $\mathrm{N}$ fertilizer effects on wheat growth and $\mathrm{N}_{2} \mathrm{O}$ emissions are needed in support of improving estimations of global $\mathrm{N}_{2} \mathrm{O}$ emissions.

The response of $\mathrm{N}_{2} \mathrm{O}$ emission to fertilization varied greatly with fertilization years (Hall and Matson, 1999), which could be ascribed to the unstable fertilization effects during the first several years of the experiment and the relatively stable effects during the middle or latter periods of the experiment. To avoid inconsistent treatment start-up responses of $\mathrm{N}_{2} \mathrm{O}$ to fertilization, $\mathrm{N}_{2} \mathrm{O}$ emissions under longterm fertilized conditions should be investigated in order to objectively determine the stable fertilization effects on $\mathrm{N}_{2} \mathrm{O}$ emissions.

In this study, a two-year $\mathrm{N}_{2} \mathrm{O}$ flux observation was conducted in a highland winter wheat field after 22 years fertilization in the Loess Plateau of China. The objective was to assess seasonal patterns of $\mathrm{N}_{2} \mathrm{O}$ flux and annual emissions as affected by long-term fertilization practices in rain-fed winter wheat field plots.

\section{Materials and methods}

\subsection{Study sites and experimental design}

The long-term field experiment was initiated in September 1984 at the Agro-ecological Experiment Station of the Chinese Academy of Science, Changwu County, Shaanxi Province, China $\left(35^{\circ} 12^{\prime} \mathrm{N}, 107^{\circ} 40^{\prime} \mathrm{E}\right)$. The average annual temperature of this site is $9.1{ }^{\circ} \mathrm{C}$ and annual precipitation is $585 \mathrm{~mm}$. The soil is a Hei Lu soil according to the Chinese classification system, which corresponds to a Calcarid Regosol according to the FAO/UNESCO classification system (FAO/Unesco, 1988).

The cropping system was continuously cropped winter wheat (Triticum aestivum $\mathrm{L}$.). The fertilizer treatments were unfertilized control $(\mathrm{CK})$, manure $(\mathrm{M})$, nitrogen $(\mathrm{N})$, nitrogen + phosphorus (NP), and nitrogen + phosphorus + manure (NPM). Urea and superphosphate were used as the source of $\mathrm{N}$ and $\mathrm{P}$. The manure came from cattle. In all of the fertilizer treatments, the $\mathrm{N}$ rate was $120 \mathrm{~kg} \mathrm{ha}^{-1}$, the $\mathrm{P}$ rate was $26.2 \mathrm{~kg} \mathrm{ha}^{-1}$, and the $\mathrm{m}$ rate was $75 \mathrm{ton} \mathrm{ha}^{-1}$. The mean total $\mathrm{N}$ content of the manure was $1.97 \mathrm{~g} \mathrm{~kg}^{-1}$ and the available $\mathrm{N}$ was $91 \mathrm{mg} \mathrm{kg}^{-1}$.

Fertilization treatments were replicated three times in a randomized complete block statistical design. Each plot was $10.3 \mathrm{~m}$ by $6.5 \mathrm{~m}$. Routine crop management practices for this region were used. Prior to seeding, fertilizers were broadcast on the soil surface and then the land was plowed two times 
Table 1. Soil fertility after 22 years of fertilization management $(0-20 \mathrm{~cm})$.

\begin{tabular}{lccccccc}
\hline Treatments & $\begin{array}{c}\text { Organic C } \\
\left(\mathrm{Mg} \mathrm{ha}^{-1}\right)\end{array}$ & $\begin{array}{c}\text { Total N } \\
\left(\mathrm{Mg} \mathrm{ha}^{-1}\right)\end{array}$ & $\begin{array}{c}\text { Total P } \\
\left(\mathrm{Mg} \mathrm{ha}^{-1}\right)\end{array}$ & $\begin{array}{c}\text { Available N } \\
\left(\mathrm{kg} \mathrm{ha}^{-1}\right)\end{array}$ & $\begin{array}{c}\text { Available P } \\
\left(\mathrm{kg} \mathrm{ha}^{-1}\right)\end{array}$ & $\begin{array}{c}\text { Available K } \\
\left(\mathrm{kg} \mathrm{ha}^{-1}\right)\end{array}$ & $\begin{array}{c}\mathrm{C} / \mathrm{N} \\
\text { CK }\end{array}$ \\
\hline 16.5 & 2.3 & 1.3 & 110 & 13 & 368 & 7.3 \\
M & 24.1 & 2.6 & 1.5 & 158 & 65 & 1024 & 9.0 \\
N & 17.8 & 2.4 & 1.6 & 136 & 14 & 371 & 7.4 \\
NP & 20.1 & 2.3 & 2.0 & 148 & 36 & 624 & 8.8 \\
NPM & 24.9 & 2.9 & 2.2 & 182 & 102 & 849 & 8.9 \\
\hline
\end{tabular}

with a cattle-drawn plow to a depth of about $10-\mathrm{cm}$. Wheat was sown in rows $20 \mathrm{~cm}$ apart. After seeding, the soil was raked to cover the seed. Weeds were removed by hand in all of the treatments. When the wheat reached maturity, it was harvested at the ground-level, the straw and grain were removed, and then the soil was plowed two times to a depth of about $15 \mathrm{~cm}$.

\subsection{Measurement of $\mathrm{N}_{2} \mathrm{O}$ flux}

The $\mathrm{N}_{2} \mathrm{O}$ fluxes were measured from September 2006 to September 2008. The soil fertility conditions in each treatment before $\mathrm{N}_{2} \mathrm{O}$ flux measurement are shown in Table 1 .

A static closed-chamber technique was used to investigate $\mathrm{N}_{2} \mathrm{O}$ flux. The chambers, with base area of $20 \mathrm{~cm} \times 25 \mathrm{~cm}$ and height of $20 \mathrm{~cm}$, made of polyvinyl chloride, were inserted $10 \mathrm{~cm}$ into the ground in each plot. The chambers remained open (uncovered) between each measurement period. Chambers were closed (covered) to begin a measurement period. Four samples, at intervals of $15 \mathrm{~min}$ each, were collected from enclosed interspaces with a $25 \mathrm{~mL}$ glass gas-tight syringe. Tang et al. (2006) showed that greenhouse gases fluxes, including $\mathrm{N}_{2} \mathrm{O}$, measured at 9:00 a.m. were close to daily means, so we collected gas samples near 9:00 a.m. every 10 days in the winter and every 4-6 days in the other seasons.

A gas chromatograph (Shimadzu GC-14B), fitted with a $4 \mathrm{~mm} \times 3 \mathrm{~m}$ stainless steel column packed with Porapack Q (80-100 mesh) and an ${ }^{63} \mathrm{Ni}$ electron capture detector (ECD), was used to measure $\mathrm{N}_{2} \mathrm{O}$ concentrations. Highpurity $\mathrm{Ar}_{2} / \mathrm{CH}_{4}\left(95 \% \mathrm{Ar}_{2}+5 \% \mathrm{CH}_{4}\right)$ was used as the carrier gas, and the flow rate was maintained at $40 \mathrm{~mL} \mathrm{~min}^{-1}$. The column and the detector temperatures were set at 65 and $300{ }^{\circ} \mathrm{C}$, respectively. The standard $\mathrm{N}_{2} \mathrm{O}$ gas was supplied by the Japanese National Institute of Agro-Environmental Sciences.

\subsection{Climate and soil environment measurements}

The climate data were determined at a weather station at the Agro-ecological Experiment Station, part of the Chinese Ecosystem Research Network (CERN). Hourly values of rainfall and air temperature at a $1.2 \mathrm{~m}$ height were mea- sured automatically at the weather station. Daily values, from 10:00 a.m. to 10:00 a.m. the following day, of rainfall and air temperature were determined from hourly values.

Soil temperature and moisture (volumetric water content) at a depth of $5 \mathrm{~cm}$ were monitored by a Delta-T Profile Probe (ML2X) and $\mathrm{HH} 2$ reader (Delta-T Devices Ltd, UK) in each plot at the time when gas samples were collected. Waterfilled pore space (WFPS) was calculated using the measured soil bulk density data and an assumed particle density value of $2.65 \mathrm{~g} \mathrm{~cm}^{-3}$.

\subsection{Statistical analysis}

The frequency distributions of observed $\mathrm{N}_{2} \mathrm{O}$ fluxes were tested. The $\mathrm{N}_{2} \mathrm{O}$ flux data in this study showed log normal or highly skewed distributions. Therefore, the original data were log-transformed to meet the normality criteria before performing ANOVA analysis. The repeated measures ANOVA was used to test the effects of fertilization and growth stage on soil $\mathrm{N}_{2} \mathrm{O}$ flux. A correlation analysis was conducted to assess the relationships between $\mathrm{N}_{2} \mathrm{O}$ flux and soil temperature and WFPS for each fertilization treatment. All statistical analyses were performed using SAS software (SAS Institute, 1999).

\section{Results}

\subsection{Overview of environmental conditions}

In this study, an observation year included a winter wheat season (from September to June in the following year) and a fallow season (June to September). The mean daily air temperatures at the study site for the 2006-2007 and the 2007-2008 observation years were $10.8^{\circ} \mathrm{C}$ and $9.6^{\circ} \mathrm{C}$, respectively. In these 2 observation years, the winter wheat seasons were characterized by relatively low air temperatures, which were $12.7^{\circ} \mathrm{C}$ and $13.9^{\circ} \mathrm{C}$ lower than those in the respective fallow seasons. Generally, the lowest daily air temperatures were observed in December and January (within the wheat season) while the highest daily air temperatures were observed in July (within the fallow season) (Fig. 1a). The rainfalls for the 2 observation years were 358 


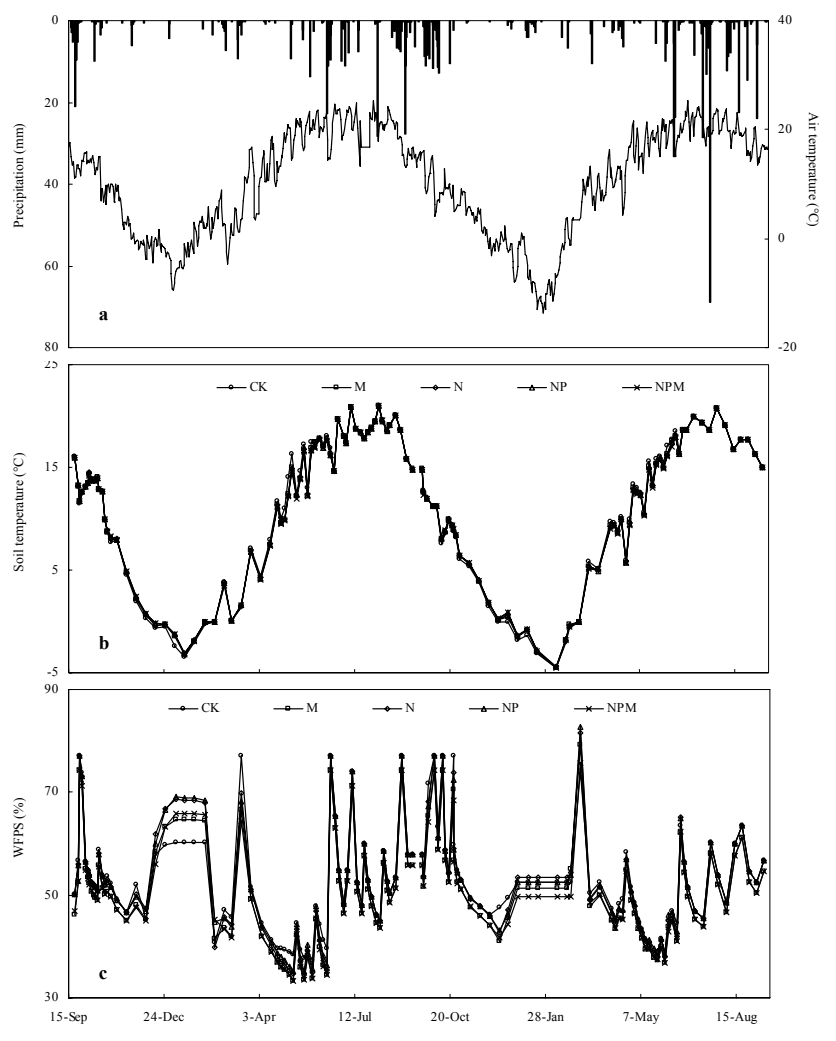

Fig. 1. Precipitation and air temperature (a), $5 \mathrm{~cm}$ depth soil temperature (b) and WFPS (c) for different fertilization treatments from September 2006 until September 2008.

and $509 \mathrm{~mm}$, of which 55 and $53 \%$ fell during the periods of winter wheat growth (Fig. 1a). The average daily rainfalls were 0.72 and $0.99 \mathrm{~mm}$ for the wheat seasons, and 1.74 and $2.6 \mathrm{~mm}$ during the fallow seasons, respectively. Therefore, the study site was characterized by dry and cold wheat seasons and wet and warm fallow seasons.

Soil temperature $(5 \mathrm{~cm}$ depth) varied seasonally in response to air temperature (Fig. 1b). The largest soil temperature (observed in CK) occurred in August, while the smallest soil temperature occurred (observed in NPM) in February. Soil temperatures in $\mathrm{CK}$ were $0-2.4{ }^{\circ} \mathrm{C}$ and $0-$ $2.0^{\circ} \mathrm{C}$ larger than in the fertilized treatment for 2006-2007 and 2007-2008 observation years depending on the sampling date. Nevertheless, the repeated measures ANOVA showed that fertilization did not significantly influence soil temperature.

Relatively large WFPS of surface soil was observed during the study period, and it varied temporally in response to rainfall and wheat growth (Fig. 1c). For the 2 observation years, WFPS was highest during the wet season and decreased during wheat growth. Soil WFPS was significantly influenced by fertilization. Generally, CK, N and NP had WFPS ranging from 37.3 to $77.1 \%, 34.5$ to $81.5 \%$ and 35.1 to $82.8 \%$, while $\mathrm{m}$ and NPM had WFPS ranging from 33.4 to $79.1 \%$

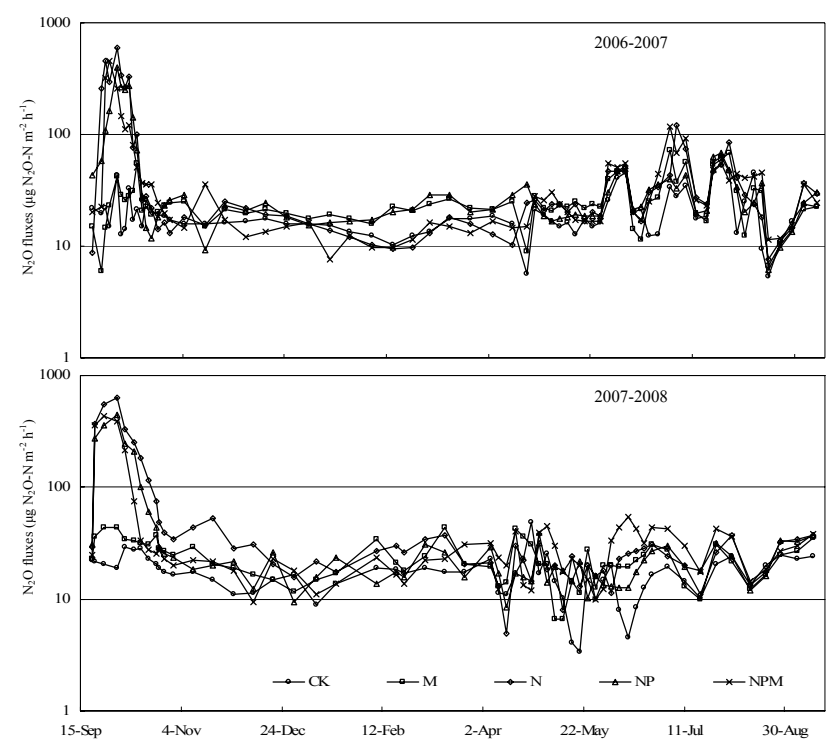

Fig. 2. $\mathrm{N}_{2} \mathrm{O}$ fluxes for different fertilization treatments from September 2006 until September 2008.

and 33.4 to $75.8 \%$, respectively. The WFPS in CK, $\mathrm{N}$ and NP were 3 to $20 \%$ higher than in $\mathrm{m}$ and NPM.

\subsection{Fertilization effects on $\mathrm{N}_{2} \mathrm{O}$ fluxes}

Soil $\mathrm{N}_{2} \mathrm{O}$ fluxes were temporally variable and fertilization dependent (Fig. 2). For the $\mathrm{CK}$ treatment, $\mathrm{N}_{2} \mathrm{O}$ fluxes ranged from 3 to $63 \mu \mathrm{g} \mathrm{N} \mathrm{N}_{2} \mathrm{O}-\mathrm{N} \mathrm{m}^{-2} \mathrm{~h}^{-1}$, with average fluxes of 21 and $18 \mu \mathrm{g} \mathrm{N} \mathrm{N}_{2} \mathrm{O}-\mathrm{N} \mathrm{m}^{-2} \mathrm{~h}^{-1}$ for 2006-2007 and 2007-2008 observation years. The largest $\mathrm{N}_{2} \mathrm{O}$ fluxes occurred in warm and wet seasons. Application of manure slightly increased the $\mathrm{N}_{2} \mathrm{O}$ flux. The average fluxes in the $\mathrm{m}$ treatment were 25 and $35 \%$ higher than those in CK for the 2 observation years, respectively. The application of N, NP and NPM significantly increased $\mathrm{N}_{2} \mathrm{O}$ fluxes. For the observation period from 2006 to 2008, the fluxes in N, NP and NPM ranged from 4.9 to $624,6.1$ to 445 , and 7.6 to $454 \mu \mathrm{g} \mathrm{N} \mathrm{N}_{2} \mathrm{O}-\mathrm{N} \mathrm{m}^{-2} \mathrm{~h}^{-1}$, with average fluxes of 64,48 and $48 \mu \mathrm{g} \mathrm{N}_{2} \mathrm{O}-\mathrm{N} \mathrm{m}^{-2} \mathrm{~h}^{-1}$, which were $3.3,2.5$ and 2.5 times the average flux in $\mathrm{CK}$.

Generally, the largest increase in $\mathrm{N}_{2} \mathrm{O}$ flux due to fertilization was observed in the 2007-2008 observation year. The $\mathrm{N}_{2} \mathrm{O}$ fluxes for the $\mathrm{N}$ and NP treatments in 2007-2008 were 1.1 times greater than those in 2006-2007.

Significant increases in $\mathrm{N}_{2} \mathrm{O}$ flux due to fertilization occurred mainly in the first 30 days after fertilization (Table 2). For example, the average $\mathrm{N}_{2} \mathrm{O}$ flux in the first 30 days after fertilization were $1057 \%, 681 \%$ and $614 \%$ larger in the N, NP and NPM treatments than in the CK treatment during the 2 observation years (2006-2008), while the average flux in the following periods (31-315 days) were $42 \%, 26 \%$ and $44 \%$ larger than in CK, respectively. Additionally, the effects of fertilization on $\mathrm{N}_{2} \mathrm{O}$ fluxes in the first 30 days were 
Table 2. Mean $\mathrm{N}_{2} \mathrm{O}$ fluxes during the first 30 days after fertilization and during the most of the year (the later period).

\begin{tabular}{|c|c|c|c|c|c|c|c|c|c|c|}
\hline & & \multicolumn{3}{|c|}{ Whole year } & \multicolumn{3}{|c|}{ First 30 days after fertilization } & \multicolumn{3}{|c|}{ Later period (31-365 days) } \\
\hline & & $2006-2007$ & 2007- 2008 & 2006-2008 & $2006-2007$ & 2007-2008 & 2006-2008 & 2006-2007 & 2007-2008 & 2006-2008 \\
\hline \multicolumn{2}{|l|}{ Precipitation (mm) } & 358 & 509 & 456 & 57 & 100 & 90 & 300 & 409 & 366 \\
\hline \multicolumn{2}{|l|}{ Soil temperature $\left({ }^{\circ} \mathrm{C}\right)$} & 10.8 & 9.6 & 10.1 & 13.9 & 10.6 & 12.1 & 10.8 & 9.5 & 9.9 \\
\hline \multirow{5}{*}{ Flux $\left(\mu \mathrm{g} \mathrm{N}_{2} \mathrm{O}-\mathrm{N} \mathrm{m}^{-2} \mathrm{~h}^{-1}\right)$} & $\mathrm{CK}$ & 21 & 18 & 20 & 22 & 24 & 23 & 21 & 17 & 19 \\
\hline & M & 26 & 24 & 26 & 25 & 35 & 30 & 26 & 22 & 24 \\
\hline & $\mathrm{N}$ & 64 & 66 & 81 & 215 & 282 & 275 & 27 & 25 & 27 \\
\hline & NP & 48 & 48 & 59 & 141 & 197 & 183 & 26 & 20 & 24 \\
\hline & NPM & 48 & 50 & 59 & 130 & 176 & 169 & 29 & 25 & 27 \\
\hline \multicolumn{2}{|l|}{$F$} & 4.50 & 3.69 & 11.38 & 7.03 & 8.07 & 14.37 & 1.65 & 8.29 & 5.98 \\
\hline \multicolumn{2}{|l|}{$p$} & 0.0015 & 0.0060 & $<0.0001$ & $<0.0001$ & 0.0002 & $<0.0001$ & 0.1621 & $<0.0001$ & 0.0001 \\
\hline
\end{tabular}

Table 3. $\mathrm{N}_{2} \mathrm{O}$ fluxes in growing seasons and fallow season as affected by fertilization.

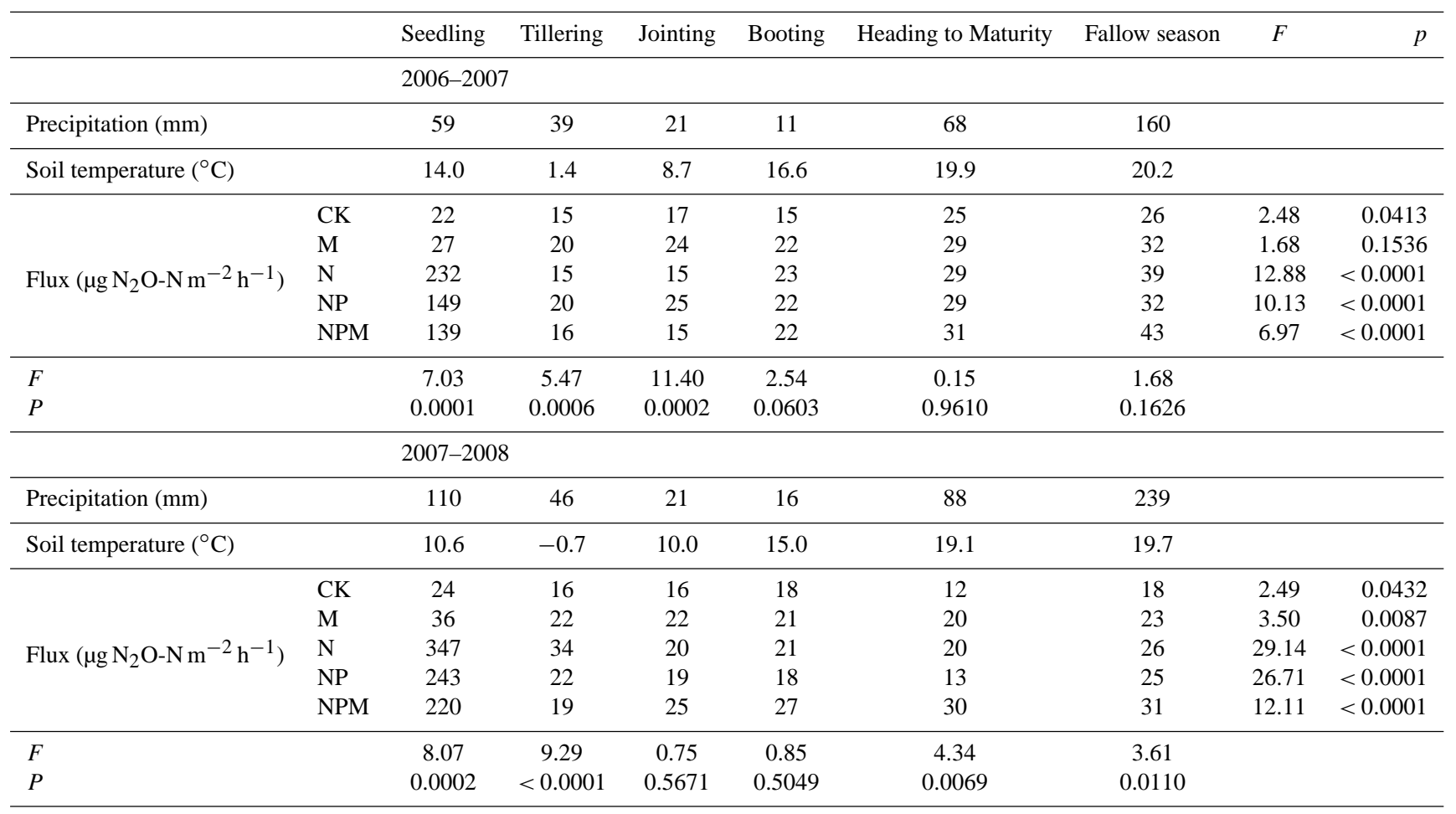

dependent on temperature and rainfall. The increases were smaller in the relatively warm and dry 2006-2007 compared to the colder and wetter 2007-2008 for the M, N, NP and NPM treatments.

Relative to $\mathrm{CK}$, the $\mathrm{N}$ treatment had the largest increases in $\mathrm{N}_{2} \mathrm{O}$ flux with an increase range of $0-605 \mu \mathrm{g} \mathrm{N}_{2} \mathrm{O}$ $\mathrm{N} \mathrm{m}^{-2} \mathrm{~h}^{-1}$ during the 2 experimental years, while the $\mathrm{m}$ treatment had the lowest increase in flux, ranging from 0 to $38 \mu \mathrm{g} \mathrm{N} \mathrm{N}_{2} \mathrm{O}-\mathrm{N} \mathrm{m}^{-2} \mathrm{~h}^{-1}$. The increases by the NP and NPM treatments ranged from 0 to $426 \mu \mathrm{g} \mathrm{N}_{2} \mathrm{O}-\mathrm{N} \mathrm{m}^{-2} \mathrm{~h}^{-1}$ and 0 to $438 \mu \mathrm{g} \mathrm{N} \mathrm{N}_{2} \mathrm{O}-\mathrm{N} \mathrm{m}^{-2} \mathrm{~h}^{-1}$, respectively, indicating that phosphorous or manure could partly offset the single mineral $\mathrm{N}$ fertilizer induced increases in $\mathrm{N}_{2} \mathrm{O}$ flux. In this study, the phosphorous and manure + phosphorous offset $36 \%$ and $35 \%$ of the increased fluxes associated with by mineral $\mathrm{N}$ fertilizer alone.

\subsection{Seasonal patterns of $\mathrm{N}_{2} \mathrm{O}$ fluxes as influenced by fertilization}

The seasonal patterns of soil $\mathrm{N}_{2} \mathrm{O}$ fluxes were mainly influenced by fertilization, wheat growth, and environmental conditions (Fig. 2 and Table 3). Both CK and $\mathrm{m}$ treatments had relatively low $\mathrm{N}_{2} \mathrm{O}$ fluxes, and the fluxes in both treatments 


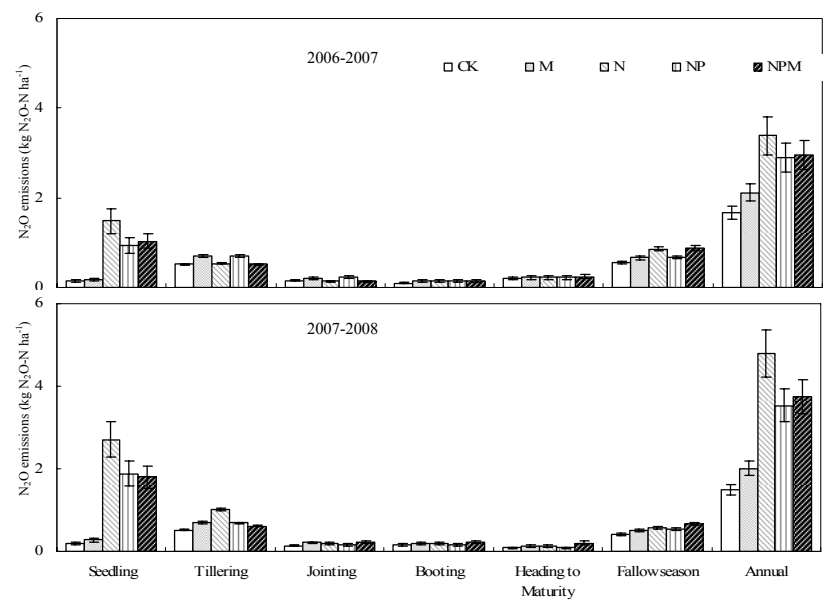

Fig. 3. Changes in $\mathrm{N}_{2} \mathrm{O}$ emissions with winter wheat growth for different fertilization treatments from September 2006 until September 2008.

could be viewed as background fluxes for the site. The background fluxes were higher in the relatively wet and warm seedling period and during the maturity stages and fallow season compared with the dryer and colder growth stages in 2006-2007. Larger background $\mathrm{N}_{2} \mathrm{O}$ fluxes corresponded to larger soil WFPS and/or temperature. Fertilization significantly influenced treatments, N, NP, and NPM, and the fluxes were largest in the seedling stage with average values of $>130 \mu \mathrm{g} \mathrm{N} \mathrm{N}_{2} \mathrm{O}-\mathrm{N} \mathrm{m}^{-2} \mathrm{~h}^{-1}$ for both 2006-2007 and 2007-2008. However, in the other growing stages and the fallow season, the average fluxes were less than $45 \mu \mathrm{g} \mathrm{N} \mathrm{N}_{2} \mathrm{O}$ $\mathrm{N} \mathrm{m}^{-2} \mathrm{~h}^{-1}$, although they were relatively large during the dryer and warmer fallow season.

The seasonal patterns of $\mathrm{N}_{2} \mathrm{O}$ flux varied with fertilizations. The fluxes in the fertilized treatments $(\mathrm{M}, \mathrm{N}, \mathrm{NP}$, and NPM) were nearly always larger than in the CK treatment during the growing seasons and fallow seasons in 2006-2007 and 2007-2008. However, the fluxes in the fertilized treatments were not significantly different in the later growing stages and the fallow seasons. These results indicated that $\mathrm{N}_{2} \mathrm{O}$ fluxes at the seedling stage were mainly controlled by nitrogen fertilization, while fluxes at the other growing stages were mainly influenced by plant and environmental conditions.

\subsection{Overall emissions}

The overall $\mathrm{N}_{2} \mathrm{O}$ emissions were generally always larger in the fertilized treatments than in the CK treatment for the growing season and the fallow season (Fig. 3). Significant differences in emissions among the five treatments occurred in the seedling, tillering, jointing stages and the fallow season during 2006-2007, and in all of the growing stages and the fallow season for 2007-2008. The lowest increases of $\mathrm{N}_{2} \mathrm{O}$ emissions during the growing season and fallow season oc-

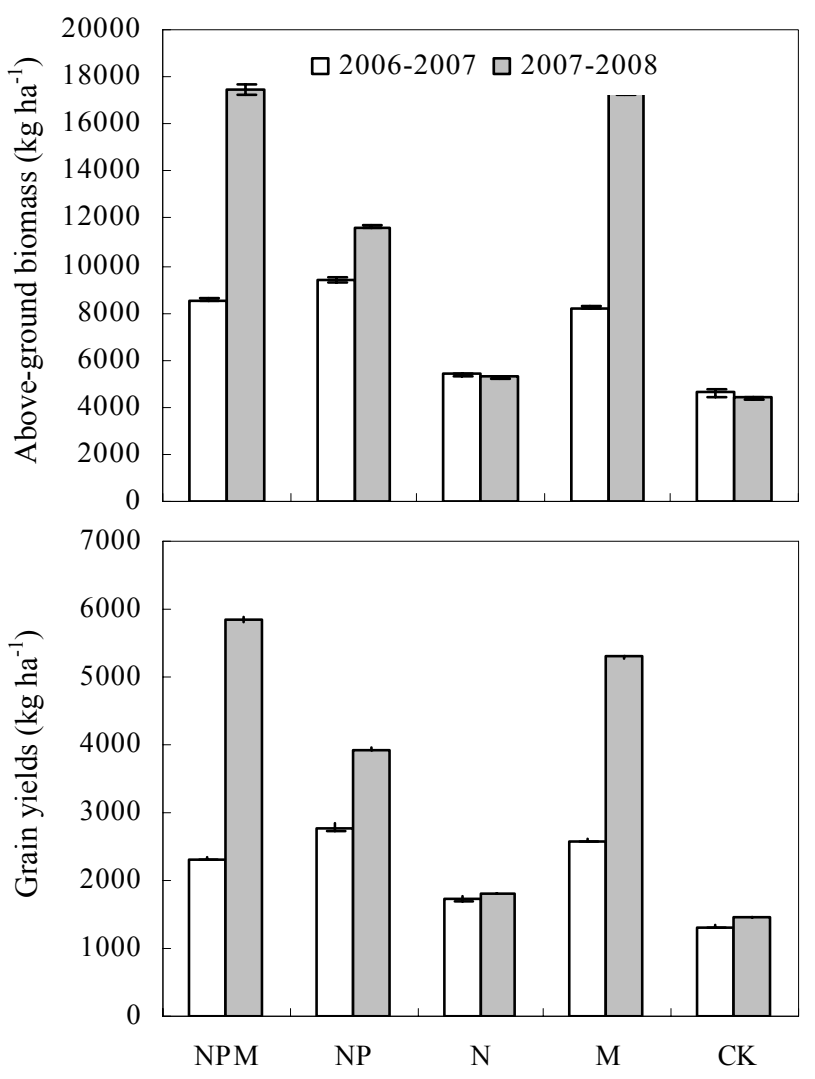

Fig. 4. Above-ground biomass and grain yields of winter wheat for different fertilization treatments from September 2006 until September 2008.

curred in $\mathrm{M}$, and the largest increases occurred in the $\mathrm{N}$ treatment. Although the NP and NPM treatments also resulted in increases in $\mathrm{N}_{2} \mathrm{O}$ emissions, the increases were less than the single mineral $\mathrm{N}$ fertilizer ( $\mathrm{N}$ treatment) increase, suggesting that phosphorous and manure fertilizers have the potential to inhibit the mineral $\mathrm{N}$ fertilizer increased $\mathrm{N}_{2} \mathrm{O}$ emission in the studied area.

For the observation year 2007-2008, the emissions for all treatments were larger from seedling to booting and lower in heading to maturity and in the fallow season compared with 2006-2007. Totally, $191 \mathrm{~mm}$ and $130 \mathrm{~mm}$ of rain occurred from seedling to booting in 2007-2008 and 2006-2007, indicating that rainfall during this period may have had more influence on the $\mathrm{N}_{2} \mathrm{O}$ emissions more than did the fertilizers. The effects of fertilization on emissions varied with rainfall. The annual emissions in CK and $\mathrm{m}$ were $10.7 \%$ and $5.1 \%$ less in the wetter 2007-2008 than in the dryer 2006-2007, while for N, NP and NPM, emissions were $41.3 \%, 22.1 \%$ and $26.6 \%$ larger in 2007-2008 than in 2006-2007, demonstrating that nitrogen fertilizer enhanced $\mathrm{N}_{2} \mathrm{O}$ emissions more in the wetter year than in the dryer year, in the seedling to booting stages. 

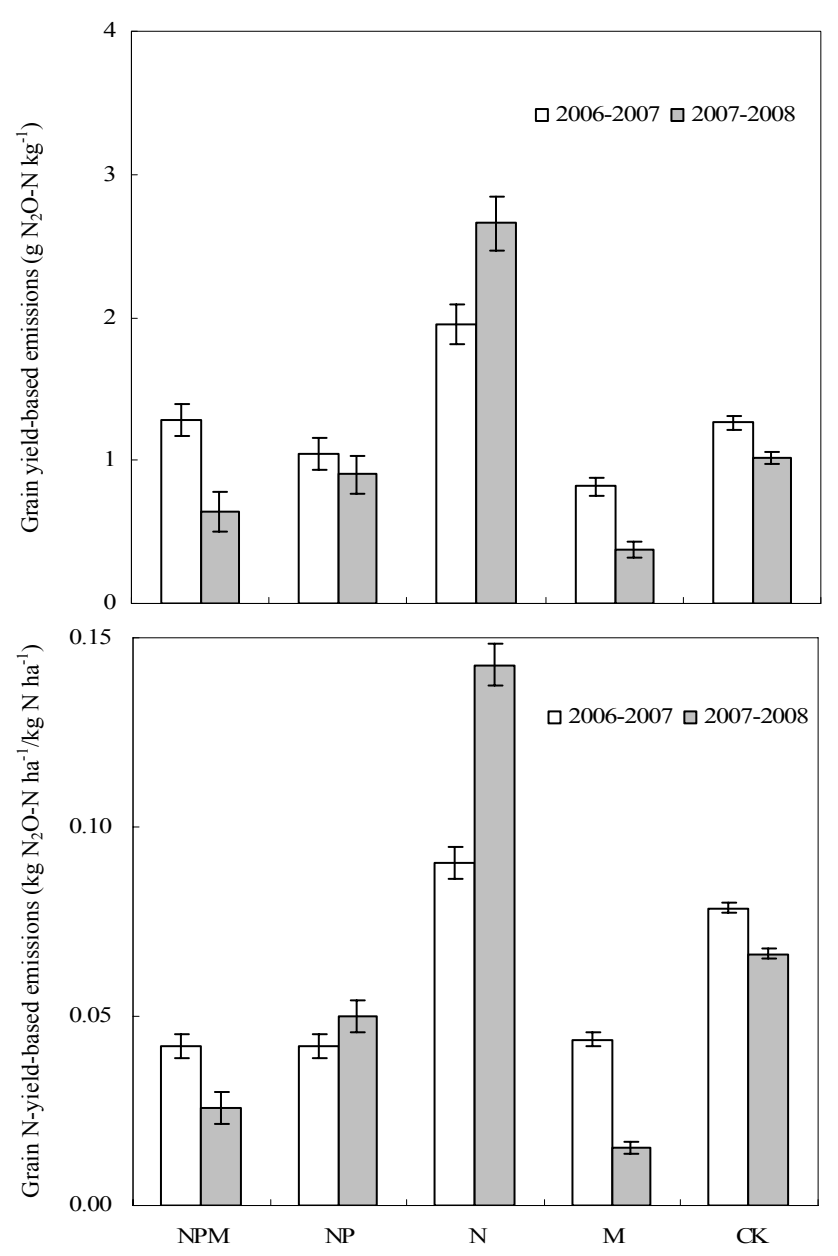

Fig. 5. Grain yield-based and grain $\mathrm{N}$-yield-based $\mathrm{N}_{2} \mathrm{O}-\mathrm{N}$ emissions for different fertilization treatments from September 2006 until September 2008.

Because the major aim of fertilization is to increase crop yields, expressing $\mathrm{N}_{2} \mathrm{O}$ emissions on a grain yield basis provides a useful option for evaluating fertilizer impacts. The biomass and grain yields in the NP, $\mathrm{m}$ and NPM treatments were significantly larger than those in the $\mathrm{N}$ and $\mathrm{CK}$ treatments for both 2006-2007 and 2007-2008 (Fig. 4). The crop grain yield-based and grain $\mathrm{N}$-yield-based $\mathrm{N}_{2} \mathrm{O}$ emissions were significantly larger in the $\mathrm{N}$ treatment than in the $\mathrm{CK}$ treatment, while those in the NP, M, and NPM treatments were lower than that in the $\mathrm{CK}$ treatment (except for the grain yield-based emissions in the NPM treatment in 2006-2007, which was similar to CK) (Fig. 5). Therefore, the combination of $\mathrm{N}$ fertilizer with $\mathrm{P}$ or manure improved the production and the environmental effects compared to single $\mathrm{N}$ fertilization alone.

\section{Discussion}

\subsection{Fertilization effects on $\mathrm{N}_{2} \mathrm{O}$ fluxes}

In our experiment, $\mathrm{N}_{2} \mathrm{O}$ flux peaks just after nitrogen fertilizer applications. The annual average fluxes due to fertilization were relatively large compared to reported fluxes from other ecosystems. Generally, the $\mathrm{N}_{2} \mathrm{O}$ fluxes in forest soils and grassland are typically low, and increases associated with $\mathrm{N}$ fertilizer applications are also low compared with farmland (Davidson and Kingerlee, 1997, Hall and Matson, 1999; Venterea et al., 2003; Du et al., 2006; Zhang and Han, 2008). The limited effects of $\mathrm{N}$ fertilizer for forest and grassland soil might be due to the relatively low $\mathrm{N}$ application levels, while the relatively large input of $\mathrm{N}$ fertilizer to crop soil often results in a large $\mathrm{N}_{2} \mathrm{O}$ flux (Wagner-Riddle et al., 2007; Barton et al., 2008; Scheer et al., 2008). Irrigation in cropped soil also enhances $\mathrm{N}_{2} \mathrm{O}$ flux (Scheer et al., 2008). The variation of soil $\mathrm{N}_{2} \mathrm{O}$ flux with ecosystem type and fertilization practices can be explained by changes in soil $\mathrm{C} / \mathrm{N}$ ratio which is negatively related with $\mathrm{N}_{2} \mathrm{O}$ flux (Klemedtsson et al., 2005). Generally, top soils in forests and grasslands have larger $\mathrm{C} / \mathrm{N}$ ratios than do farmland soils, and the soils with large $\mathrm{C} / \mathrm{N}$ ratios have lower $\mathrm{N}_{2} \mathrm{O}$ fluxes. The application of mineral $\mathrm{N}$ fertilizer to soil reduces the $\mathrm{C} / \mathrm{N}$ ratio, and thus increases $\mathrm{N}_{2} \mathrm{O}$ flux. Soil $\mathrm{C} / \mathrm{N}$ ratios of the farmland in our site are larger than those observed by Scheer et al. (2008) and smaller than those by Wagner-Riddle et al. (2007) and Barton et al. (2008), and our fluxes in the CK and mineral $\mathrm{N}$ fertilized treatments are smaller than those reported by Scheer et al. (2008) and larger than those reported by Wagner-Riddle et al. (2007) and Barton et al. (2008). The application of manure fertilizer often increases the $\mathrm{C} / \mathrm{N}$ ratio and consequently decreases the $\mathrm{N}_{2} \mathrm{O}$ flux. The top soil $\mathrm{C} / \mathrm{N}$ ratios followed the order of $\mathrm{M}>\mathrm{NPM}>\mathrm{N}$ while the fluxes followed the order of $\mathrm{M}<\mathrm{NPM}<\mathrm{N}$.

The application of manure fertilizer often improves soil structure (Bronick and Lal, 2005), increases soil porosity, and decreases WFPS, which reduces the denitrification rate and thus decreases $\mathrm{N}_{2} \mathrm{O}$ emissions. Liu et al. (2000) and Huo et al. (2008) reported that manure fertilizer has a large potential to increase soil porosity and aggregation in the Loess Plateau, which improves soil aeration. In our study, the WFPS in CK, N and NP were 3 to $20 \%$ higher than in $\mathrm{m}$ and NPM, which partly explains the manure effects on $\mathrm{N}_{2} \mathrm{O}$ emissions.

Although several studies demonstrated that $\mathrm{P}$ promotes $\mathrm{N}_{2} \mathrm{O}$ flux (Minami and Fukushi, 1983; Falkiner et al., 1993; Zhang and Han, 2008), we observed $24 \%$ and $27 \%$ lower fluxes in the NP treatment than in the N treatment in 20062007 and 2007-2008, indicating that $\mathrm{P}$ could alleviate single $\mathrm{N}$ fertilizer increases of $\mathrm{N}_{2} \mathrm{O}$ flux. We assume that this effect is due to the fact that the NP treatment accelerated the uptake of soil mineral $\mathrm{N}$ which decreased soil nitrate and ammonium levels compared with the $\mathrm{N}$ treatment. The lower the soil $\mathrm{N}$, 
Table 4. Co-relationships between $\mathrm{N}_{2} \mathrm{O}$ fluxes and soil temperature and water-filled pore space (WFPS).

\begin{tabular}{lccccccc}
\hline & & CK & M & N & NP & NPM & All treatments \\
\hline \multirow{2}{*}{ Soil temperature } & $r$ & 0.2386 & 0.2058 & 0.0750 & 0.0839 & 0.1412 & 0.0833 \\
& $p$ & 0.0076 & 0.0217 & 0.4080 & 0.3544 & 0.1177 & 0.0381 \\
WFPS & $r$ & 0.1693 & 0.1243 & 0.3710 & 0.3163 & 0.3667 & 0.2760 \\
& $p$ & 0.0602 & 0.1691 & $<0.0001$ & 0.0003 & $<0.0001$ & $<0.0001$ \\
\hline \multirow{2}{*}{ Soil temperature } & $r$ & 0.2515 & 0.2243 & 0.2170 & 0.2610 & 0.5171 & 0.2865 \\
& $p$ & 0.0097 & 0.0214 & 0.0260 & 0.0072 & $<0.0001$ & $<0.0001$ \\
WFPS & $r$ & 0.1489 & 0.0776 & 0.1562 & 0.1318 & 0.0224 & 0.0903 \\
& $p$ & 0.1294 & 0.4315 & 0.1117 & 0.1801 & 0.8208 & 0.0386 \\
\hline
\end{tabular}

the lower the substrate for $\mathrm{N}_{2} \mathrm{O}$ production. The uptakes of $\mathrm{N}$ by winter wheat in 2006-2007 and 2007-2008 were 109\% and $67 \%$ higher in NP than in N, while the residual nitrate and ammonium in the top soil $(0-10 \mathrm{~cm})$ were $23 \%$ and $13 \%$, and $35 \%$ and $6 \%$ less in the NP treatment than in the N treatment.

\subsection{Seasonal patterns}

The fertilizations significantly affected the seasonal patterns of soil $\mathrm{N}_{2} \mathrm{O}$ fluxes, which were characterized by a peak flux within 30 days following fertilization, consistent with other findings (Hall and Matson, 1999). For the whole wheat season and fallow season, the flux was significantly related with soil temperature for each treatment. Except for the seedling period, the seasonal patterns of $\mathrm{N}_{2} \mathrm{O}$ flux in all treatments were closely related with WFPS (Table 4), indicating that $\mathrm{N}_{2} \mathrm{O}$ fluxes in the winter wheat fields of the study area were somewhat temperature and water dependent.

The dependence of $\mathrm{N}_{2} \mathrm{O}$ production on soil temperature has been reported in many ecosystems (Dobbie and Smith, 2003a; Flynn et al., 2005; Wagner-Riddle et al., 2007; Zhang and Han, 2008). A threshold of $5{ }^{\circ} \mathrm{C}$ for $\mathrm{N}_{2} \mathrm{O}$ productioN has been reported (Dobbie and Smith, 2003b). According to this threshold, there should be little $\mathrm{N}_{2} \mathrm{O}$ flux in the littering stage. However, winter and spring thaw could magnify $\mathrm{N}_{2} \mathrm{O}$ fluxes because freeze/thaw cycles have been related to enhanced microbial activity due to increased available carbon from freezing lysis (Christensen and Tiedje, 1990), and disintegrating aggregates (van Bochove et al., 2000), combined with sufficient soil water content during thawing (Lemke et al., 1998). Combined, these conditions can result in a relatively large flux in the littering stage. Wagner-Riddle et al. (2007) also observed increased $\mathrm{N}_{2} \mathrm{O}$ in cold seasons, agreeing with our measurements. Additionally, large available $\mathrm{N}$ in soils during the stage following the seedling stage (when the fertilizer was applied) might be another reason for the higher fluxes in the nitrogen fertilized treatment.

In our study, 93\% of the observed WFPS values were lower than $70 \%$, which is the threshold for denitrification dominance (Davidson, 1992), suggesting that nitrification is likely the main source of $\mathrm{N}_{2} \mathrm{O}$ in our study. The seasonal patterns of winter wheat growth and WFPS differed significantly with fertilization, indicating that the effects of fertilization on temporal $\mathrm{N}_{2} \mathrm{O}$ fluxes in the growing season were mainly associated with wheat root activities and WFPS changes, which alter soil microorganism activities in $\mathrm{N}_{2} \mathrm{O}$ production together with soil $\mathrm{C}$ and $\mathrm{N}$ conditions. The effects in the fallow season were dominated by the WFPS and soil $\mathrm{C}$ and $\mathrm{N}$ conditions.

\section{Implications for $\mathrm{N}_{2} \mathrm{O}$ emission and fertilization}

At the global scale, annual $\mathrm{N}_{2} \mathrm{O}$ emissions from cropped mineral soils ranged from 0.3 to $10.7 \mathrm{~kg} \mathrm{~N}_{2} \mathrm{O}-\mathrm{N} \mathrm{ha}^{-1} \mathrm{yr}^{-1}$ (Stehfest and Bouwman, 2006). For wheat soils, the emission ranged from 0.5 to $3.7 \mathrm{~kg} \mathrm{~N}_{2} \mathrm{O}-\mathrm{N} \mathrm{ha}^{-1} \mathrm{yr}^{-1}$ regardless of irrigation or not, while more than $75 \%$ of these observations were less than $1.6 \mathrm{~kg} \mathrm{~N}_{2} \mathrm{O}-\mathrm{N} \mathrm{ha}^{-1} \mathrm{yr}^{-1}$ (Roelandt et al., 2005). The background emissions (CK treatment) in our rain-fed winter wheat field were 1.7 and $1.9 \mathrm{~kg} \mathrm{~N}_{2} \mathrm{O}-\mathrm{N} \mathrm{ha}^{-1}$ $\mathrm{yr}^{-1}$, while our fertilized emissions were 2.1-3.4 and 3.2$7.5 \mathrm{~kg} \mathrm{~N}_{2} \mathrm{O}-\mathrm{N} \mathrm{ha}^{-1} \mathrm{yr}^{-1}$ for the 2006-2007 and 2007-2008 observation years. These were relatively large emission values.

The annual $\mathrm{N}_{2} \mathrm{O}$ emissions from fertilized treatments were in the following order $\mathrm{N}>\mathrm{NPM}$ and $\mathrm{NP}>>\mathrm{M}$, suggesting that the contribution of single $\mathrm{N}$ fertilizer alone was larger than that of NP and NPM. This finding agrees with other reports (Flynn et al., 2005; Dambreville et al., 2008; Alluvione et al., 2010). This result implies that the present assessment 
might be larger because manure and phosphorous fertilizers are widely used in agriculture together with mineral $\mathrm{N}$ fertilizer while its role in offsetting mineral $\mathrm{N}$ fertilizers induced $\mathrm{N}_{2} \mathrm{O}$ emissions are usually neglected. Barton et al. (2008) also suggested that the observed emission factor in semiarid cropped soil is 60 times less than the values suggested by IPCC. Many estimations separate fertilizer $\mathrm{N}$ as mineral $\mathrm{N}$ and organic N (from manure fertilizer) (Flynn et al., 2005, Davidson, 2009) without considering the fact that organic $\mathrm{N}$ and mineral $\mathrm{N}$ and mineral $\mathrm{N}$ and $\mathrm{P}$ are often used together. These estimations often ignore the offsetting role of manure when it is applied together with mineral $\mathrm{N}$ fertilizers.

Our results further show that the $m$ treatment had relatively large biomass and grain yield and relatively low $\mathrm{N}_{2} \mathrm{O}$ fluxes and annual emissions. From the point of agricultural production and $\mathrm{N}_{2} \mathrm{O}$ emission, $\mathrm{M}$ is recommended while single $\mathrm{N}$ fertilization alone is not recommended for highland winter wheat, when fertilizers are applied at the time of planting.

Acknowledgements. This study was supported by the National Key Basic Research Special Foundation Project (2005CB121101, 2009CB118604), the Knowledge Innovation Program of Chinese Academy of Sciences (KZCX2-YW-424-3, KSCX-YW-09-07), National Natural Science Foundation of China (40801111), the Program for Youthful Talents in Northwest A \& F University and the Chinese Academy of Sciences Visiting Professorship for Senior International Scientists (2009Z2-37).

Edited by: A. Neftel

\section{References}

Alluvione, F., Bertora, C., Zavattaro, L., and Grignani, C.: Nitrous oxide and carbon dioxide emissions following green manure and compost fertilization in corn, Soil Sci. Soc. Am. J., 74, 384-395, 2010.

Barton, L., Kiese, R., Gatter, R., ButterbachBahl, K., Buck, R., Hinz, C., and Murphy, D. V.: Nitrous oxide emissions from a cropped soil in a semi-arid climate, Global Change Biol., 14, 177-192, 2008.

Bouwman, A. F.: Exchange of greenhouse gases between terrestrial ecosystems and the atmosphere, in: Soils and the Greenhouse Effect, edited by: Bouwman, A. F., Wiley, New York, 249-279, 1990.

Bouwman, A. F., Boumans, L. J. M., and Batjes, N. H.: Emissions of $\mathrm{N}_{2} \mathrm{O}$ and $\mathrm{NO}$ from fertilized fields: Summary of available measurement data, Global Biogeochem. Cy., 16, 1058-1070, 2002.

Bouwman, A. F., Van Drecht, G., and van der Hoek, K. W.: Surface $\mathrm{N}$ balances and reactive $\mathrm{N}$ loss to the environment from global intensive agricultural production systems for the period 19702030, Sci. China Ser. C., 48, 767-779, 2005.

Bronick, C. J. and Lal, T.: Soil structure and management: a review, Geoderma, 124, 3-22, 2005.

Christensen, S. and Tiedje, J. M.: Brief and vigorous $\mathrm{N}_{2} \mathrm{O}$ production by soil at spring thaw, J. Soil Sci., 41, 1-4, 1990.
Dambreville, C., Morvan, T., and Germon, J. C.: $\mathrm{N}_{2} \mathrm{O}$ emission in maize-crops fertilized with pig slurry, matured pig manure or ammonium nitrate in Brittany, Agr. Ecosys. Environ., 123, 201210, 2008.

Davidson, E. A.: Sources of nitric oxide and nitrous oxide following wetting of dry soil, Soil Sci. Soc. Am. J., 56, 95-102, 1992.

Davidson, E. A.: The contribution of manure and fertilizer nitrogen to atmospheric nitrous oxide since 1860 , Nat. Geosci., 2, 659662, 2009.

Davidson, E. A. and Kingerlee, W. A.: Global inventory of nitric oxide emissions from soils, Nutr. Cycl. Agroecosys., 48, 37-50, 1997.

Dittert, K., Lampe, C., Gasche, R., Butterbach-Bahl, K., Wachendorf, M., Papen, H., Sattelmacher, B., and Taube, F.: Short-term effects of single or combined application of mineral $\mathrm{N}$ fertilizer and cattle slurry on the fluxes of radiatively active trace gases from grassland soil, Soil Biol. Biochem., 37, 1665-1674, 2005.

Dobbie, K. E. and Smith, K. A.: Nitrous oxide emission factors for agriculture soils in Great Britain: the impact of soil water filled pore spore space and other controlling variables, Global Change Biol., 9, 204-218, 2003a.

Dobbie, K. E. and Smith, K. A.: Impact of different forms of N fertilizer on $\mathrm{N}_{2} \mathrm{O}$ emissions from intensive grassland, Nutr. Cycl. Agroecosys., 67, 37-46, $2003 \mathrm{~b}$.

Du, R., Lu, D., and Wang, G. L: Diurnal, seasonal, and interannual variations of $\mathrm{N}_{2} \mathrm{O}$ fluxes from native semi-arid grassland soils of inner Mongolia, Soil Biol. Biochem., 38, 3474-3482, 2006.

Falkiner, R. A., Khanna, P. K., and Raison, R. J.: Effect of superphosphate addition on nitrogen mineralization and nitrification in several forest soils, Aust. J. Soil Res., 31, 285-296, 1993.

FAO/Unesco,: Soil Map of the World, Revised Legend, FAO, Rome, 1988.

Flynn, H. C., Smith, J. U., Smith, K. A., Wright, J., Smith, P., and Massheder, J.: Climate- and crop responsive emission factors significantly alter estimates of current and future nitrous oxide emissions from fertilizer use, Global Change Biol., 11, 15221536, 2005.

Forster, P., Ramaswamy, V., Artaxo, P., Berntsen, T., Betts, R., Fahey, D. W., Haywood, J., Lean, J., Lowe, D. C., Myhre, G., Nganga, J., Prinn, R., Raga, G., Schulz, M., Van Dorland, R., Forster, P., Ramaswamy, V., and Artaxo, P.: Changes in atmospheric constituents and in radiative forcing, in: IPCC Climate Change 2007: The Physical Science Basis, edited by: Solomon, S., Qin, D. H., Manning, M., et al.), Cambridge Univ. Press, 129234, 2007.

Hall, S. J. and Matson, P. A.: Nitrogen oxide emissions after nitrogen additions in tropical forests, Nature, 400, 152-155, 1999.

Hao, M. D., Zhang, J. X., and Hu, K. C.: The fertilization in agricultural production of the middle Loess Plateau, in: Comprehensive Research of Effective Eco-economic Systems in Wangdonggou, Changwu, edited by: Li, Y. S. and Su, S. M., Science and Technology Press, Beijing, 182-187, 1991.

Huo, L., Wu, T. Y., Lin, H. M., Cao, S. Y., and Tang, W. X.: Effects of long-term fertilization on water stable aggregates in calcic kastanozem of the Loess Plateau, Chin. J. Appl. Ecol., 19(3), 545-550, 2008.

Klemedtsson, L., von Arnold, K., Weslien, P., and Gundersen, P.: Soil CN ratio as a scalar parameter to predict nitrous oxide emissions, Global Change Biol., 11, 1142-1147, 2005. 
Lampe, C., Dittert, K., Sattelmacher, B., Wachendorf, M., Loges, R., and Taube, F.: Sources and rates of nitrous oxide emissions from grazed grassland after application of ${ }^{15} \mathrm{~N}$-labelled mineral fertilizer and slurry, Soil Biol. Biochem., 38, 2602-2613, 2006.

Lemke, R. L., Izaurralde, R. C., and Nyborg, M.: Seasonal distribution of nitrous oxide emissions from soil in the Parkland region, Soil Sci. Soc. Am. J., 62, 1320-1326, 1998.

Liu, J., Chang, Q. R., Li, G., and Wei, Y. S.: Effect of different fertilization on soil characteristics of aggregate, Bull Soil Water Conserv., 20(4), 24-26, 2000.

McSwiney, C. and Robertson, G. P.: Nonlinear response of $\mathrm{N}_{2} \mathrm{O}$ flux to incremental fertilizer addition in a continuous maize (Zea mays L.) cropping system, Global Change Biol., 11, 1712-1719, 2005.

Minami, K. and Fukushi, S.: Effects of phosphate and calcium carbonate application on emission of $\mathrm{N}_{2} \mathrm{O}$ from soils under aerobic conditions, Soil Sci. Plant Nutr., 29, 517-524, 1983.

Raun, W. R. and Johnson, G. V.: Improving nitrogen use efficiency for cereal production, Agron. J., 91, 357-363, 1999.

Roelandt, C., van Wesemael, B., and Rounsevell, M.: Estimating annual $\mathrm{N}_{2} \mathrm{O}$ emissions from agricultural soils in temperate climates, Global Change Biol., 11, 1701-1711, 2005.

SAS Institute Inc: SAS user's guide, Version 8, Cary NC, 1999.

Scheer, C., Wassmann, R., Kienzler, K., Ibragimov, N., Lamers, J. P. A., and Martius, C.: Methane and nitrous oxide fluxes in annual and perennial land-use systems of the irrigated areas in the Aral Sea Basin, Global Change Biol., 14, 2454-2468, 2008.

Shen, S. M.: Soil fertility in China. Chinese Agricultural Press, Beijing, 1998.

Silgram, M., Waring, R., Anthony, S., and Webb, J.: Intercomparison of national \& IPCC methods for estimating $\mathrm{N}$ loss from agricultural land, Nutr. Cycl. Agroecosys., 60, 189-195, 2001.

Stehfest, E. and Bouwman, L.: $\mathrm{N}_{2} \mathrm{O}$ and $\mathrm{NO}$ emission from agricultural fields and soils under natural vegetation: summarizing available measurement data and modeling of global annual emissions, Nutr. Cycl. Agroecosys., 74, 207-228, 2006.
Sudling, K. N., Collins, S. L., Gough, L., Clark, C., Cleland, E. E., Gross, K. L., Milchunas, D. G., and Pennings, S.: Functionaland abundance-based mechanisms explain diversity loss due to N fertilization, PNAS, 102, 4387-4392, 2005.

Tang, X. L., Liu, S. G., Zhou, G. Y., Zhang, D. Q., and Zhou, C. Y.: Soil-atmospheric exchange of $\mathrm{CO}_{2}, \mathrm{CH}_{4}$, and $\mathrm{N}_{2} \mathrm{O}$ in three subtropical forest ecosystems in southern China, Global Change Biol., 12, 546-560, 2006.

van Bochove, E., Jones, H. G., Bertrand, N., and Prevost, D.: Winter fluxes of greenhouse gases from snow-covered agricultural soil: intra-annual and interannual variations, Global Biogeochem. Сy., 14, 113-125, 2000.

Venterea, R. T., Groffman, P. M., Verchot, L. V., Magill, A. H., Aber, J. D., and Steudler, P. A.: Nirogen oxide emission from temperate forest receiving long-term nitrogen input, Global Change Biol., 9, 346-357, 2003.

Vitousek, P. M., Naylor, R., Crews, T., David, M. B., Drinkwater, L. E., Holland, E., Johnes, P. J., Katzenberger, J., Martinelli, L. A., Matson, P. A., Nziguheba, G., Ojima, D., Palm, C. A., Robertson, G. P., Sanchez, P. A., Townsend, A. R., and Zhang, F. S.: Nutrient Imbalances in Agricultural Development, Science, 324, 15191520, 2009.

Wagner-Riddle, C., Furon, A., Mclaughlin, N. L., Lee, I., Barbeau, J., Jayasundara, S., Parkin, G., Von Bertoldi, P., and Warland, J.: Intensive measurement of nitrous oxide emissions from a cornsoybean-wheat rotation under two contrasting management systems over 5 years, Global Change Biol., 13, 1722-1736, 2007.

Xing, G. X. and Zhu, Z. L.: An assessment of N loss from agricultural fields to the environment in China, Nutr. Cycl. Agroecosys., 57, 67-73, 2000.

Zhang, J. F. and Han, X. G.: $\mathrm{N}_{2} \mathrm{O}$ emission from the semi-arid ecosystem under mineral fertilizer (urea and superphosphate) and increased precipitation in northern China, Atm. Environ., 42, 291-302, 2008. 